\title{
Effectiveness of Health Teaching on Women's Knowledge and Skills Regarding Breast Self-Examination in Primary Health Centers in Erbil City/Iraq
}

Kareem Fattah Aziz; Department of Nursing, College of Nursing, Hawler Medical University, Erbil, Iraq. (Correspondence: kareem.fattah@nur.hmu.edu.krd)

Shayma Sameer Maqsud; Department of Nursing, College of Nursing, Hawler Medical University, Erbil, Iraq.

\section{ABSTRACT}

Background and objectives: Breast cancer is a general term used for different types of cancers that develop from breast tissue cells. Breast self-examination may help detection of breast cancer in early time. The aim of the study is to identify women's knowledge and skills about Breast Self-Examination. The objectives of the study was to identify the overall effectiveness of health teaching on knowledge and skills of women about Breast SelfExamination.

Methods: A Quasi-experimental study was conducted on 100 women who attended to three main primary health care centers in Erbil city during November 2017 to April 2018. Data collection was done two times, one before teaching session and second after that through direct interview and a questionnaire format. Chi-square test was used for comparing pre and post -test results of the study sample.

Results: Regarding level of knowledge about Breast Self-Examination the results revealed that there were three levels as: poor $28 \%$, fair $49 \%$ and good $23 \%$. Regarding their skills about Breast Self-Examination, the results indicated that there were three categories as poor $78 \%$, fair $6 \%$ and good $16 \%$. There was significant difference between overall knowledge and skills of participants before and after teaching session.

Conclusion: Teaching session was effective on Breast Self-Examination knowledge and skills. Public education can be developed by health policy in the region in order to breast cancer prevention and early detection.

Keywords: Breast Self-Examination, Knowledge, Skills.

Received: $25 / 7 / 2018$

Accepted: 15/1/2019

Published: $30 / 5 / 2019$

\section{INTRODUCTION}

The main causes of mortality and morbidity among women in developed and developing countries are breast cancer [1].In Malaysia, there is the most common cancer among women regardless of ethnic groups and begin from age 15 onwards [2]. Clinical breast examination, mammography and Breast self-examination BSE may help detection of breast cancer in early time. [3]. BSE alone is not enough for early detection of breast cancer, but it is still an important screening tool for early detection of breast cancer in most developing countries, because it is cheap, widely available, and does not need difficult technical training [4]. Practicing BSE help a woman to be familiar with her normal breast structure, helps her to learn and see any abnormal changes in her breast tissue, size or shape of her breast. [5] Most studies indicated that the majority of Malaysian women have not enough knowledge about breast cancer, and other research demonstrated that breast self-examination practices have a significant association with breast cancer knowledge [6] Breast cancer is the main causes of morbidity and mortality among 
women and with a high rate especially the malignancy cancer every year, nearly one million new cases of breast cancer are diagnosed worldwide. There were about 519,000 women who die from breast cancer annually and about one millions of women develop breast cancer each year and information by WHO, 2010 [7]. Breast cancer is the second cause of death among women in the Eastern Mediterranean Region and it is a general term used for different types of cancers that develop from breast tissue cells and also it is an uncontrolled growth of malignant tissue (uncontrolled and causes death) that arises in the breast [8]. Breast self-examination is necessary for women to know any abnormality in their breast. But early breast cancer is often found on a mammogram (for women 45 years and older) before a lump can be felt. [9]. The woman's chances of developing breast cancer increase with age, i.e. as a woman ages, her likelihood of developing breast cancer also increases. Close to 80 percent of breast cancers occur in women age 45 or older. The rates of breast cancer in young women actually quite low, but they increase rapidly with advancing age state that, many patients do not realize the impact of age on risk. They often 10 overestimate or underestimate their risk of breast cancer. Although breast cancer can strike both men and women, the majority of breast cancer occurs in women. Less than $1 \%$ of all cases are diagnosed in men. In fact, being female is the single greatest risk factor for breast cancer. [10] High dose radiation exposure is associated with increased breast cancer risk. [11]. Clinical breast examination CBE is performed by advanced practice nurses and other healthcare providers. [12].The first and common sign of breast cancer is often a painless lump or thickening in the breast [13]. Agars and McMurray reported that breast cancer continues to have no exact known cause or primary prevention. [14]. The rates of breast cancer in young women actually quite low, but they increase rapidly with advancing age [15]. This study aimed to assess women's knowledge and skills about BSE and to identify the overall effectiveness of health teaching contents on knowledge and skills of women about Breast Self-Examination BSE.

\section{METHODS}

The design of the study included a quasiexperimental study and it was conducted to evaluate the effect of teaching on knowledge and skills of women regarding BSE. The sample size was included 100 women who attended to three primary health care centers in Erbil city (Mala Fandi, Nazdar Bamarni and Kurdistan) according to geographical area of Erbil city, depending on a non-probability convenient sampling method. The study was begun from 1-Nov-2017 to 1-April-2018. A questionnaire format was used for data collection which developed according massive review literature. The questionnaire was reviewed by panel of experts in nursing field for validity and according their comments the questionnaire was revised and it included three parts: part one sociodemographic data and part two questions related to knowledge on BSE and part three related to skills of women about BSE. Data collected in two different days: first day pre-test and conducting teaching session and second day posttest done on theoretical and skills of BSE. Regarding ethical consideration, the approval was taken from Ethical Committee/College of Nursing. Agreement was taken from General Directorate of Health in Erbil City. The informed consent was taken from all study sample after explaining the purpose and knowing right of withdraw during study. Regarding the contents of health teaching it was focused on the importance of BSE 
and breast cancer prevention and early detection as general and specifically focused on knowledge of BSE and skills of performing BSE. There was no any exclusion criteria just refusing to participation. The data entered in Statistical Package of Social Science (SPSS) version 23 and analyzed with descriptive and inferential statistics (frequency, percentage, chi-square).

\section{RESULTS}

Table 1 indicated that the highest percentage of the sample study was between the age of (16-30) years, the highest percentage of them graduated from secondary school, majority of them were housewife, which represented 93\%, most of them were married which represented $78 \%$, while majority of them were from urban which represented $82 \%$, and most of them were having no history of breast cancer, half of them had more than two children while majority of them had more than two years of marriage.

Table 1: Socio-demographic characteristics of the sample study

\begin{tabular}{|c|c|c|c|}
\hline Socio-demographic & Categories & $\mathbf{F}$ & $\%$ \\
\hline \multirow[t]{3}{*}{ Age group/ } & $16-30$ & $47(47)$ & $47(47)$ \\
\hline & $31-45$ & $38(38)$ & $38(38)$ \\
\hline & $46-60$ & $15(15)$ & $15(15)$ \\
\hline \multirow[t]{4}{*}{ Level of education } & Illiterate & $26(26)$ & $26(26)$ \\
\hline & Primary & $31(31)$ & $31(31)$ \\
\hline & Secondary & $36(36)$ & $36(36)$ \\
\hline & Bachelor & $7(7)$ & $7(7)$ \\
\hline \multicolumn{4}{|l|}{ Occupational status. } \\
\hline & House wife & 93(93) & $93(93)$ \\
\hline & Employee & $5(5)$ & $5(5)$ \\
\hline \multirow[t]{3}{*}{ History of Breast cancer. } & Unskilled & $2(2)$ & $2(2)$ \\
\hline & Present & $11(11)$ & $11(11)$ \\
\hline & Not present & $89(89)$ & $89(89)$ \\
\hline \multicolumn{4}{|l|}{ Marital status } \\
\hline & Marriage & $78(78)$ & $78(78)$ \\
\hline & Single & 19(19) & 19(19) \\
\hline & Widowed & $3(3)$ & $3(3)$ \\
\hline \multicolumn{4}{|l|}{ Years of marriage } \\
\hline & Not marriage & 19(19) & 19(19) \\
\hline & One year & $4(4)$ & $4(4)$ \\
\hline & Two years & $14(14)$ & $14(14)$ \\
\hline & More than 2 & $63(63)$ & $63(63)$ \\
\hline \multicolumn{4}{|l|}{ Number of children } \\
\hline & None & 19(19) & 19(19) \\
\hline & One & $15(15)$ & $15(15)$ \\
\hline & Two & $14(14)$ & $14(14)$ \\
\hline & More than 2 & $52(52)$ & $52(52)$ \\
\hline \multicolumn{4}{|l|}{ Residential area } \\
\hline & Urban & $82(82)$ & $82(82)$ \\
\hline & Suburbs & $10(10)$ & $10(10)$ \\
\hline & Rural & $8(8)$ & $8(8)$ \\
\hline
\end{tabular}


Table 2 revealed that overall knowledge of sample study was classified in to three levels as following poor level $28 \%$, fair level $49 \%$ and good level $23 \%$ in pre-test while the capacity of knowledge for all women had improved properly to $100 \%$ in posttest, because of effectiveness of application health teaching .

Table 3 indicated that the skills of women about BSE were classified into three levels poor $78 \%$, fair $6 \%$ and good $16 \%$ in pretest, while in post-test the skills were improved properly to $100 \%$ because of the effectiveness of health teaching.

Table 4 indicated overall knowledge and skills of sample about BSE. There were highly significant differences between pretest and post-test $(13.9 \pm 5.89,24.9 \pm 0.17)$ this was interpreted that teaching that was applied for them was effective on their knowledge and skills about BSE.

Table 2: Overall Knowledge level on BSE

\begin{tabular}{lcccc}
\hline \multirow{2}{*}{ Overall Knowledge } & \multicolumn{2}{c}{ Pre-Test } & \multicolumn{3}{c}{ Post test -Test } \\
\cline { 2 - 5 } & F & $\%$ & F & $\%$ \\
\hline Poor & & & & \\
Fair & $28(28)$ & $28(28)$ & $0(0)$ & $0(0)$ \\
Good & $49(49)$ & $49(49)$ & $0(0)$ & $0(0)$ \\
Total & $23(23)$ & $23(23)$ & $100(100)$ & $100(100)$ \\
& $(100)$ & $(100)$ & $(100)$ & $(100)$ \\
\hline
\end{tabular}

Table 3: Overall skill level of Breast Self-Examination BSE

\begin{tabular}{lcccc}
\hline \multirow{2}{*}{ Overall Practice } & \multicolumn{2}{c}{ Pre-test } & \multicolumn{3}{c}{ Post-test } \\
\cline { 2 - 5 } & F & $\%$ & F & $\%$ \\
\hline Poor & $78(78)$ & $78(78)$ & $0(0)$ & $0(0)$ \\
Fair & $6(6)$ & $6(6)$ & $0(0)$ & $0(0)$ \\
Good & $16(16)$ & $16(16)$ & $100(100)$ & $100(100)$ \\
Total & 100 & 100 & 100 & 100 \\
\hline
\end{tabular}

Table 4: Overall Knowledge and skills of BSE

\begin{tabular}{llll}
\hline Overall Knowledge ,skills & Pre-test & Post-test & P-Value Paired t-test \\
\hline & $\mathrm{M} \pm \mathrm{SD}$ & $\mathrm{M} \pm \mathrm{SD}$ & \\
Overall Knowledge & $13.9 \pm 5.89$ & $24.9 \pm 0.17$ & $<0.001 \mathrm{VHS}$ \\
Overall Practice & $2.3 \pm 4.21$ & $12.0 \pm 0.001$ & $<0.001 \mathrm{VHS}$ \\
\hline
\end{tabular}




\section{DISCUSSION}

The results of the study indicated that sample study was classified in to three levels for each of their knowledge and skills about breast self-examination BSE these findings were agreed with a study done by Milat who found that mothers in Jeddah had little knowledge about BSE [16]. Regarding overall knowledge and skills about BSE, the study revealed that there were highly significant differences between pretest and post-test 13.9 \pm 5.89 pre-test , 24.9 \pm 0.17 post-test about their knowledge and skills, regarding breast self-examination BSE the interpretation for that due to effectiveness of teaching contents that had been implemented upon women who attending to main primary health care centers in Erbil City, this results were agreed with the study done by Elfituri A. etal, who found that it was necessary to apply the teaching process upon women to increase their knowledge and skills about BSE [17].The results of the study was also similar to the study done by Al-Tawil and Abdul Ameer who found that lack of knowledge and skills about BSE due to lack of implementation of teaching for women [18].The findings of the study revealed that teaching program was effective to change their knowledge and skills about BSE and was agreed with the study done by Abdel-Hadi who said that in Arab Countries mother's knowledge and skills toward BSE was low because of lack of teaching process [19].

The limitation of the study was sample size and refusing to participate in the teaching session.

\section{CONCLUSIONS}

The results of the study revealed that women have poor knowledge and skills regarding BSE and health teaching can improve their level of knowledge and practice. The study recommended establishing
BSE centers in main primary health care centers in Kurdistan Region for early detection and prevention from breast cancer among women as Breast Cancer Awareness Program (BCAP).

\section{CONFLICTS OF INTEREST}

The authors report no conflicts of interest.

\section{ACKNOWLEDGEMENTS}

The author would like to thank all women who participated in the study and thank all staff in dfprimary health care centers who helped to complete this study.

\section{REFERENCES}

[1] Loh SY, Chew SL. Awareness and practice of breast self- examination among Malaysian women with breast cancer. Asian Pacific Journal of Cancer Prevention, Vol 12(1): 2011, 199-202.

[2] National Cancer Registry, Malaysia Cancer Incidence in Peninsular Malaysia 2003-2005. Ministry of Health Malaysia. 2008.

[3] Giridhara RB, Goleen S, Sharon PC, Breast cancer screening among females in Iran and recommendations for improved practice: a review. Asian Pacific Journal Of Cancer Prevention: APJCP · January 2011.NO. 12(6): 1647-55.

[4] Akhtari-Zavare M1, Juni MH, Said SM, Ismail $\mathrm{I} . \mathrm{Z}$,Beliefs and behavior of Malaysia undergraduate female students in a public university toward breast self-examination practice. Asian Pacific Journal Cancer Prevention. 2013;14(1):57-61. Available from: https:// www.ncbi.nlm.nih.gov/pubmed/23534796.

[5] Fotedar V, Seam RK, Gupta MK, Knowledge of risk factors and early detection methods and practices towards breast cancer among nurses in Indira Gandhi Medical College, Shimla, Himachal Pradesh, India. Asian Pacific Journal of Cancer Prevention. 2013; 14 (1): 117-20.

[6] World Health Organization. Breast cancer: prevention and control. Available from: http://www.who.int/cancer/ detection/ breastcancer/en/index3.html. Accessed 12th May 2014. 
[7] Chong CC, Jeya DC, Balakrishnan S. Perception of breast health amongst Malaysian female adolescents. Asian Pacific Journal of Cancer Prevention. 2014; 15(17) 75-80.

[8] World Health Organization Cancer. Retrieved on 20th April accessed in: ,http:// www.who.int/ media- centre/factsheets/ fs297/en/, 2010.

[9] Lewis, J. Your Guide to Breast Cancer. London: Hodden Arnold,2005.

[10] American Cancer Society. . Cancer Facts and Figures. Atlanta, Georgia, American Cancer Society. Accessed in: American Cancer Society. Breast Cancer Facts and Figures Atlanta: Georgia: American Cancer Society 2003.

[11] Colditz, G. A. \& Stein, C. J. Handbook of Cancer Risk Assessment and Prevention. Sudbury, 22. Massachusetts: Jones and Bartlett Publishers. 10- Colditz, G. A. \& Stein, C. J. Handbook of Cancer Risk Assessment and Prevention. Sudbury, Massachusetts: Jones and Bartlett Publishers; 2004.

[12] American Cancer Society. Cancer facts and figures 2008. Atlanta, Georgia: American Cancer Society.Mason, T. E. \& White, K. M. (2008). Applying an Extended Model of the Theory of Planned Behaviour to Breast SelfExamination. Journal of Health Psychology, 2008, 13, 946-955.

[13] Lewis, J. You're Guide to Breast Cancer. London: Hodden Arnold,2005.

[14] LisaSummersCNM, DrPHMarionMcCartneyCNM, BSN. Liability Concerns: A View From the American College of NurseMidwives. Journal of Midwifery \& Women's Health November-December 2005, Pages 531-535.

[15] Colditz, G. A. \& Stein, C. J. Handbook of Cancer Risk Assessment and Prevention. Sudbury, Massachusetts: Jones and Bartlett Publishers. 2004.

[16] Milaat, knowledge of female secondary school students on breast cancer and BSE in Jeddah, Saudi Arabia 2000 /6(2/3):338343.Available from:http://2/32000.WHO.Int. (Accessed on 2 November 2008).

[17] Elfituri,AA, Elmahaish MS, and Macdonquid TH. Role of the health education program within the Libyan community. East Mediterranean Health Journal1999. 5(2):268-72.

[18] Al-Tawil NG, Abdul Ameer AJ. Al-Tawil WG.knowledge and practices of BSE among a group of women attending some medical clinic in Baghdad .Iraqi Postgraduate Medical Journal 1:279-285. 2002
[19] Abdel-Hadi MS,.Breast cancer awareness among health professionals. US National Library of Medicine National Institutes of Health: Ann Saudi Medicine, 2000, 20(2):135 -6 . 